\title{
THE BATTLE OF SANDFONTEIN: THE ROLE AND LEGACY OF MAJOR- GENERAL SIR HENRY TIMSON LUKIN ${ }^{1}$
}

\author{
Rodney C. Warwick ${ }^{2}$ \\ Diocesan College, Cape Town
}

\section{Introduction}

Commemorative statues, plaques and monuments from decades past remain widespread across both the urban and rural South Africa landscape. Included amongst these is the stone likeness of General Tim Lukin in Cape Town: just one of such structures intended to encapsulate the emotions and memories of those who commissioned it. The South African involvement at Delville Wood ninety years ago would still resonate with some of the country's population; those who at some stage have delved into reading up on the history of our participation in the First World War. However mention of the Battle of Sandfontein during the Union invasion of German South West Africa in 1914 to the same reasonably historically literate grouping, would from the larger proportion of them, most probably elicit an admittance of ignorance. Only the well-read enthusiast of South African military history would be aware of Lukin's roles at both Delville Wood and Sandfontein, let alone how the latter engagement constituted one of the bleakest moments in the General's career.

This article revives debate about this long forgotten First World War military clash in Africa: the first full set battle-piece in which the two year old Union Defence Force was involved, and which resulted in a defeat for the South African forces. It also investigates the role of General Lukin therein, and how culpability for

1 This paper was presented at the $4^{\text {th }}$ War and Society in Africa Conference: Strategy, Generalship and Command in Southern Africa: Past, Present, Future, held at the South African Military Academy, Saldanha, 4-6 September 2003. It was then entitled: Major-General Sir Henry Timson Lukin: A New Examination of an Almost Forgotten South African Military Legacy.

${ }^{2}$ Rodney Warwick teaches History at the Diocesan College (Bishops) in Cape Town. This article is largely derived from his MA dissertation in Historical Studies, "Reconsideration of the Battle of Sandfontein: The First Phase of the German South West Africa Campaign, August to September 1914", University of Cape Town (UCT), 2003. 
the Sandfontein defeat became entangled within the turbulent white South African politics of the time. Veterans' resentments of political and military misjudgements were still emerging years later. This long after a now established South African military historiography had asserted an 'official ownership' over the Sandfontein battle, its circumstances, and the roles of the leading personalities involved. Through carefully constructed accounts by these pioneer South African military historians, controversies were minimised, and aspects of both Lukin and his political master Jan Smuts's decisions were effectively sanitised. It is argued that both men were in error regarding their appreciations of how to begin the Union incursion into the southern part of German South West Africa, thereby contributing directly to the Sandfontein defeat, with Lukin as the professional soldier sharing the lesser portion of culpability. Although it was clear that ensuring the defence of the Sandfontein position had been a rash decision, Lukin as a procedurally correct civil servant, silently accepted the Sandfontein defeat as one of war's misfortunes. This military engagement's reverse for the Union Defence Force was intrinsically connected to the political intrigues behind the Union government's haste to invade German South West Africa.

It is difficult to disagree with Albert Grundlingh's contention that within South African historiography there remains a dearth of 'War and Society' studies emphasising the effect of armed conflict upon social and political change. Also, that in post-1994 South Africa, investigations into the historical contexts of our past need to be broadened regarding the re-examination of a variety of topics; in particular social history in the twentieth century, during and between the two World Wars. ${ }^{3}$ Reflecting upon Lukin and the way in which his comrades in arms chose to remember him, namely the Cape Town statue, this paper hopes to cast fresh light on our understanding of a now almost forgotten military battle in Africa. Sandfontein was one tiny fragment of a predominantly European conflict, whose eventual outcome heralded the gargantuan global struggles of the twentieth century. This paper also tries to highlight and strike a balance regarding details of Lukin's military career not dealt with by the previous hagiographic biographical writings, and where the actual Sandfontein battle also received comparatively little attention. ${ }^{4}$

\footnotetext{
${ }^{3}$ A. Grundlingh, The King's Afrikaners? Enlistment and Ethnic Identity in the Union of South Africa's Defence Force During the Second World War, 1939-45, pp.351-352, Journal of African History, 40, 1999.

${ }^{4}$ R.E. Johnston, Ulundi to Delville Wood: The Life Story of Major-General Sir Henry Timson Lukin (Maskew Miller, Cape Town, 1929), and Willem Steenkamp's, biographical account contained within his book: The Soldiers (Don Nelson, Cape Town, 1978), pp.51-82.
} 


\section{The Lukin Statue: The historical context of its commissioning}

The approximately six metre high statue of Major-General Sir Henry Timson Lukin K.C.B. C.M.G. D.S.O. Commander Legion of Honour Order of the Nile is situated just beyond the Queen Victoria street entrance of the historic Company Gardens in Cape Town. It was unveiled on the $3^{\text {rd }}$ of March 1932 by the Governor-General, the Earl of Clarendon, in front of a large crowd that included the most prominent figures of white South African politics, besides scores of exservicemen and nurses from the Union Defence Force's First World War ranks, many of whom wore their war decorations for the occasion. ${ }^{5}$ Today it would be doubtful as to whether more than a miniscule percentage of the population who walk past the statue have any inkling as to who he was, or for that matter why such a prominent monument was once conceived appropriate. Lukin and his legacy are now virtually extinguished from the collective historical memory of Cape Town.

Ironically, the editorials within both the city's leading English-language newspapers on the day following the statue's unveiling, strongly stressed a belief that Lukin's memorial would serve as an inspiration for future generations to rise above themselves during times of extreme adversity. ${ }^{6}$ Yet the statue's size and positional prominence are indicative of the esteem Lukin's name still held in 1932 by at least white Capetonians and South Africans, particularly those who served under his command during the Great War. Its construction was funded by donations collected by a committee established after the General's death in December 1925. This body was tasked to create a National Memorial intended to include both a one thousand pound University scholarship for sons of South African World War One veterans, and the erection of a statue in Cape Town. ${ }^{7}$ There were also minted medallions and the setting up of commemorative plaques in various locations around the country. If statues can be said to represent an ancient art form to venerate or remind future generations of deities, or the lives of deceased persons of prominence, then the motivation behind the construction of that intended to honour Lukin deserves investigation, albeit seventy-four years later. Such a study is particularly valid if upon reflecting on components of Lukin's military career, it assists us in clarifying aspects of his generalship during the First World War, and improves our historical understanding of the society that clearly once held him in great awe.

\footnotetext{
${ }^{5}$ Cape Times, 4 March 1932, p.13.

${ }^{6}$ Cape Times, 4 March 1932, p.10; Cape Argus, 4 March 1932, p.10.

${ }^{7}$ Johnston, Ulundi to Delville Wood, pp.227-228.
} 
Present at the statute unveiling on that early autumn day were two former Cape Mounted Rifles and Union Defence Force comrades, Brigadier-Generals J.J. Collyer and R.C. Grant, ${ }^{8}$ who may well have mused quietly to themselves about events during August-September 1914 when Lukin was dealt particularly difficult cards by Jan Smuts. The first phase of the German South West Africa Campaign was wracked with controversy, specifically the circumstances surrounding the lost battle of Sandfontein on 26 September 1914. Against a background of compelling political and military imperatives, the contested issues of culpability for the Sandfontein defeat and Lukin's involvement therein, were to remain largely muted within the broader record of South African military involvement during 1914-18. ${ }^{9}$

The statue's unveiling resulted in the contemporary Cape Town newspapers recording several substantially descriptive and glowing statements pertaining to the General's reputation, mirroring the public perceptions of his former subordinates and the public. The Cape Argus remarked on the likeness with a journalistic reverence: "He stands four-square, imperturbable, a little inscrutable, above all, a man among men." 10 The Cape Times was even more gushing and inaccurately prophetic: His greatness was recognised in his life; in death it seems still greater. Cape Town will treasure his memorial, as the mayor said yesterday, and will hold it in trust for South Africa, present and future. ${ }^{11}$

Even the Afrikaner Nationalist Cape daily Die Burger, conceded that Lukin had been regarded with love and respect by his men. ${ }^{12}$ It is unnecessary to recall in any detail how the National Party under Hertzog had in 1914 called in vain for South African neutrality, in response to Louis Botha and Jan Smuts contending that the Union government was honour-bound to acknowledge the ties of Empire. That Die Burger had less to say on Lukin compared to the South African Party supporting papers was unsurprising, for the National Party had been attacked in Parliament after the war for allegedly denigrating Union war veterans. In 1920, Nongqui, the 'inhouse' monthly publication for the SA Mounted Rifles, Police, and Prisons Service, referred to MP John X. Merriman remarking at how pained he was that the returned soldiers had been discussed in a disreputable manner by the

\footnotetext{
${ }^{8}$ Their presence at the unveiling is confirmed in the Cape Times, 4 March 1932, p.13.

${ }^{9}$ R.C. Warwick, "Reconsideration of the Battle of Sandfontein: The First Phase of the German South West Africa Campaign, August-September 1914", MA thesis, University of Cape Town, 2003 , attempts to deal with this assertion in detail as one of its themes. The author has tried to summarise part of his arguments in this paper.

${ }^{10}$ Cape Argus, 4 March 1932, p.10.

${ }^{11}$ Cape Times, 4 March 1932, p.10.

${ }^{12}$ Die Burger, 4 March 1932, p.3.
} 
Nationalists, and that "our men had a reputation for gallantry, discipline, and intelligence, and everywhere, except in our dirty politics, our men were honoured". ${ }^{13}$

The statue's unveiling also occurred during the grey days of the early 1930s world-wide economic depression, where gloom, cynicism and doubt prevailed about democracy, capitalism, and the kind of World bequeathed after the Great War, with the apparently temporary and misleading prosperity during the 1920s. The South African economic plight and the accompanying party political conflict reflected those around the world. Lukin's commemoration took place against angry debates in Parliament about the plight of the poor, (mostly Afrikaner) whites, white unemployment in general, and whether the country should move off the Gold Standard. The unveiling was a momentary, if artificial respite to inflamed national issues, but it also represented a poignant moment where the contemporary political ideal of building a united white South African nation, was symbolised by a ceremonial occasion which recalled when white South Africans had fought grimly side by side for the British Empire on distant battlefields during 1914-18.

Lukin's own strong belief in white reconciliation was endorsed by his hard fighting experiences during the 1899-1902 South African War. He held the command of all Cape Colonial Forces responsible for guarding the eastern districts of the Colony. During the guerrilla phase he had personally been involved in some of the most bitter fighting where dozens of Cape Afrikaner Rebels had been executed, often after the most rudimentary of military trials. ${ }^{14}$ It has not been established whether Lukin was personally involved in any of these grim tribunals and sentences, but his regiment the CMR was certainly at the forefront of the fighting. Lukin's later reconciliatory attitude, based upon the spirit of the white Union of 1910, was maintained during the 1922 Rand white workers uprising which cut across language lines ${ }^{15}$ and in many cases tragically pitched former UDF 191418 veterans against one another. ${ }^{16}$ By the early 1920 s it was clear that Lukin identified himself both as a South African and a strong believer in the British Empire. ${ }^{17}$ Unfortunately the virtual exclusion from the white community's perceptions and interest of the significant black and coloured South African

\footnotetext{
${ }^{13}$ The Nongqai, August 1920, p.384.

${ }^{14}$ For a detailed narrative and statistics of Boers executed by Imperial Forces throughout the SA War, see G. Jooste \& R. Webster, Innocent Blood - Executions during the Anglo-Boer War (Spearhead, Claremont, Cape Town, 2002).

${ }^{15}$ Johnston, Ulundi to Delville Wood, p.211.

${ }^{16}$ For a range of examples, see N. Herd, 1922, The Revolt on the Rand (Blue Crane Books, Johannesburg, 1966).

${ }^{17}$ Johnston, Ulundi to Delville Wood, pp.211-212.
} 
participation within the Union's war effort, was sadly a blunt reflection of how little these veterans' contribution had by 1932 penetrated the collective white South African consciousness.

However, despite the racial distortions of the period, and appropriately for white politics of 1932 and the white war veterans, the statue unveiling occasion brought together the most important politicians from the National/Labour coalition Pact Government and the South African Party Official Opposition. These included Afrikaner Nationalist Republicans D.F. Malan and E.G. Janson; Leader of the Opposition and British Empire champion Jan Smuts, his close lieutenant and senior shadow cabinet minister Denys Reitz, and the future South African GovernorGeneral, Patrick Duncan. The speakers, including the Prime Minister General J.B.N. Hertzog, senior Labour Party member Colonel F.C. Cresswell, and the Mayor Mr H.J.C. Stephen, all recalled in particular the desperate struggle in July 1916 by the South African Brigade at Delville Wood. The immediate aftermath of this battle was indisputably the most important moment when Lukin was heralded in popular heroic style via the pro-war English South African press. Lukin as the Springbok Brigade's commanding officer was captured in photography and news reports, standing in tears to attention, cap in hand, as the remnants of the $1^{\text {st }}$ SA Brigade marched out the devastated wood after the horror of a desperate six days and nights of continual fighting.

Delville Wood was immortalised by both the press and South African First World War military historiography. The latter writings began to appear during the early $1920 \mathrm{~s}^{18}$ and formed part of the unifying mythology of the dominant white political order. ${ }^{19}$ When the memorial was unveiled in October 1926, political representatives of both white communities in the form of Sir Percy FitzPatrick and General Hertzog, spoke in the most extravagant language of "the real meaning of Union", and of making the memorial and cemetery "the alter of the nation", inspiring "all that is good and noble in human action, and in national unity of heart and endeavour". ${ }^{20}$ It was however, the image of the loyal, stoic, and sorrowing commander, besides numerous other remembrances, that particularly raised the

${ }^{18}$ Specifically J. Buchan, The South African Forces in France (Nelson, 1920), and the Official History, The Union of South Africa and The Great War 1914-1915 (written by the "General Staff, Defence Headquarters", Pretoria, Government Printing and Stationary Office, 1924).

${ }^{19}$ See W. Nasson, Springboks at the Somme: The Making of Delville Wood, 1916, Seminar Paper presented on 21 October 1996 at the University of the Witwatersrand, Institute for Advanced Social Research, pp.15-17; where he elaborates strongly on this point.

${ }^{20}$ G.W. Warwick (this paper's author's great uncle), We Band of Brothers (Howard Timmins, Durban, 1962), pp.192-193. 
memory of Lukin amongst those who had served under him. The powerful camaraderie of the South African Brigade in France maintained itself in the immediate post-war years, ${ }^{21}$ cushioned no doubt by the economic upturn of the 1920s. With added maturity and material comfort, the veterans were able to reflect back with selective nostalgia on their hard formative military experiences, forged as they were in war, while the horrors were dulled, denied, or left unsaid amidst the old comrades bonding and reminiscing at social gatherings. While Field-Marshall Douglas Haig was to be considered the Butcher of the Somme by so many later historians of the Great War, then this was not obvious according to Major Piet van der Byl when the Field-Marshall visited South Africa in 1921. Haig was applauded by large numbers of South African Brigade veterans at a civic dinner in Durban, who "slightly the worse for wear", crowded around him with slaps on the back and cries of "Good old Dougie", much to the Field-Marshall's embarrassment. ${ }^{22}$

Indeed it would be unrealistic to expect that within ex-servicemen's organisations, the members of the largely middle-class all-volunteer South African Brigade, would not have re-asserted amongst themselves, the norms that Nasson refers to as their "college ethos schooling" and "shared social codes". 23 This white, largely English military veteran brotherhood took several tangible forms including the inception of the Comrades Marathon in 1921 and the creation of the Memorable Organisation for Tin Hats (MOTHS) in July 1927. ${ }^{24}$ As war appeared at least temporarily vanquished the old bonds and their concomitant social hierarchies and mores, further accentuated through shared military service, were reinvigorated via informal occasions ranging from weekly MOTH gatherings, to the dedications of memorials and formal dinners. The impulse amongst the veterans to remember and relive the brotherhood of the trenches was also reflected by a strong public affection for their old chief. Lukin retired from the military at the end of the war and declined when offered a chance to stand in a safe parliamentary seat. Instead he launched himself into a variety of other public responsibilities, but most importantly for the men he had led, he was President of the British Empire Service League in South Africa. ${ }^{25}$ As the most senior Union Defence Force veteran, Lukin was in regular demand and he retained a high public profile. $^{26}$

${ }^{21}$ See Warwick, We Band of Brothers, for an older first hand account by a veteran of the SA Brigade's comradeship and campaigning.

${ }^{22}$ P. van der Byl, Top Hat to Velskoen (Howard Timmins, Cape Town, 1973), p.18.

${ }^{23}$ Nasson, Springboks at the Somme, p.3.

${ }^{24}$ See the Moth's Annual, 1928, pp.16-18, for a reflection of the motives and ideals behind the organisation's inception.

${ }^{25}$ Johnston, Ulundi to Delville Wood, pp.203-206.

${ }^{26}$ Johnston, Ulundi to Delville Wood, pp.203-215. 


\section{Lukin: His early military career}

The product of an old and moderately prominent English family, Lukin was born on 24 May 1860 in Fulham, London. Hoping to gain a commission in a colonial regiment, he had arrived as an eighteen year old in South Africa during 1879 and enrolled into the Natal Native Contingent as a junior officer during the Anglo-Zulu War. He soldiered with conspicuous robustness and was severely wounded at the battle of Ulundi, but was rejected once again after the war for a commission within the Imperial Army. He was offered and accepted the same in March 1881 within the Cape Mounted Rifles, the Cape Colonial government's only regular military force, ${ }^{27}$ beginning a military career that initially took him through what were effectively the final black/white South African land wars of the late nineteenth century. In terms of contemporary racial attitudes, Lukin as a white colonial soldier exhibited clearly little that would have distinguished him from the settler mentality of the time. His biographer notes cheerfully that upon first arriving in Natal, after being put in charge of a group of black labourers, Lukin threatened them with a revolver after a dispute arose over pay. ${ }^{28}$ As a CMR lieutenant, in 1893 when faced with a potential uprising by the Pondos near Umtata, he successfully pacified the situation by demonstrating to the disaffected kraals a display of artillery firing on a clump of trees. ${ }^{29}$ His bluntness in dealing with conflict situations was equally legendary with white subordinates, as is revealed through a furious letter written by George Rattray, the Headmaster of Selborne College in February 1910. Lukin was by this time Commandant-General of the Cape Colonial Forces. A dispute arose between the military and educationists over the future responsibility of the school's cadet corps. Lukin was accused of having called the Headmaster "a fool in the presence of my pupils" and instructing Rattray to "lie down on the ground with them (the pupils) when he addressed the Corps instead of asking the Officers as usual to fall out" ${ }^{30}$ Johnston in his hagiographic biography defended Lukin's temperament, stating that the General's men said reverently of him: "He is a devil, but he's a just devil." ${ }^{31}$ By the achievement of the South African Union in May of 1910, Lukin was the most senior professional soldier in the country. In 1912 he was predictably appointed to one of the two most senior positions in the Union Defence

\footnotetext{
${ }^{27}$ Johnston, Ulundi to Delville Wood, chapters III-V.

${ }^{28}$ Johnston, Ulundi to Delville Wood, p.18.

${ }^{29}$ Johnston, Ulundi to Delville Wood, p.57.

${ }^{30}$ National Archives, Cape Depot (hereafter NACD), DD Volume 1\145, Ref C1129, letter dated 22 February 1910 by Capt. George Rattray to the Staff Officer to the Commandant General C.C.F. King William's Town.

${ }^{31}$ Johnston, Ulundi to Delville Wood, p.52.
} 
Force by new Defence Minister Smuts, namely that of Inspector-General of the Permanent Force.

\section{The Union Government's plan to invade German South West Africa: Prelude to the Battle of Sandfontein}

Lukin's first operational command during the First World War was 'A Force' or the 'Namaqualand Field Force'; part of a three pronged strategy to invade German South West Africa. This plan had been initially agreed upon at the highest Union government and military level during a meeting held at Defence Headquarters in Pretoria on 21 August 1914, attended by Lukin. Lieutenant-Colonel Manie Maritz commanded 'B Force' ${ }^{32}$ which was intended to assemble at Upington, while ' $\mathrm{C}$ Force' under Colonel P. Beves was to land at Luderitzbucht. ${ }^{33}$ The fact that Smuts had assigned the largest of the three invasion components, namely 'A Force', to the responsibility of the officer commanding the Permanent Force was indicative of its central significance to the Defence Minister's plan.

The five South African Mounted Rifles (SAMR) regiments of the Permanent Force, assembled in mid-August at the Rosebank Show Grounds in Cape Town. This constituted Lukin's 'A Force' and totalled 3315 white men, 5 white female nurses, and 653 black and coloured men. After landing at Port Nolloth by 7 September, entrained to Steinkopf, then marched by 12 September to the three Orange River crossing points at Goodhouse, Ramans Drift and Houms Drift, the government gave Lukin authority to enter German territory. ${ }^{34}$ Within three days several skirmishes with German forces had ensued within the colony. However, Smuts in Pretoria and the staff officers at Defence Headquarters were deeply concerned with alarming rumours circulating around the suspected disloyal demeanour of Maritz, the Union Defence Force officer appointed to command the North-West Cape military district. ${ }^{35}$ Maritz had been a prominent 'Fighting General' in the South African War, and now had under his authority several hundred men just been called up for war service of both British and Afrikaner backgrounds. They were intended as the invasion plan's second "prong", with orders to advance from Upington in support the northward thrust by Lukin towards Warmbad. Although anti-British feelings still smouldered amongst many Afrikaners in the

32 According to J.J. Collyer, The Campaign in German South West Africa, 1914-15 (Government Printer, Pretoria, 1937), p.28, this consisted of "1000 all ranks" with no artillery.

${ }^{33}$ Collyer, The Campaign in German South West Africa, p.28.

${ }^{34}$ Collyer, The Campaign in German South West Africa, p.30.

${ }^{35}$ Collyer, The Campaign in German South West Africa, p.33. 
northern Cape district, a critical feature of the initial invasion plan had astoundingly been entrusted to an officer of decidedly uncertain political loyalties.

Although Maritz had not yet formally declared his rebellion, he had already secretly colluded with the Germans before the war and had clearly harboured every intention of assisting the Kaizer's forces when and if favourable circumstances transpired. ${ }^{36}$ However during September 1914, the political reality was that Smuts and the government were acutely impatient to contest German South West Africa and secure an early victory. Given the serious domestic political tensions within the Union, the government's motive was to bolster public confidence in both its own war policy and the Union Defence Force. Faced with a looming Afrikaner nationalist rebellion, Smuts needed to rapidly reinforce the Union parliament's decision to support the British Empire by invading German South West Africa, with Lukin assigned as the hatchet-man for this political imperative. An early Union Defence Force advance from the river drifts towards Warmbad was envisaged, and such was signalled to Lukin from ministerial level at Defence Headquarter on 22-23 September. ${ }^{37}$ However, the hurried despatch of 'A Force' had been further exacerbated by its logistically extremely uneven arrival at the border, and its premature crossing into German territory on 14 September. Lukin's men began to ford the Orange River before the brigade's full strength and supplies were anywhere near the border, as is clearly shown by his force's documented logistical and intelligence inadequacies. ${ }^{38}$ The South African Mounted Rifles troops, mostly ex-frontier mounted policemen, had mobilised enthusiastically but with uncertain preparation or experience as soldiers for a conventional war. ${ }^{39}$ They were expected to immediately conduct a brigade-sized operation against a neighbouring colony, defended by a determined enemy who were well acquainted with fighting in the south of the territory through the recent Nama uprisings.

The Sandfontein disaster began to develop from 16 September when LtCol Berrangé, one of Lukin's regimental commanders, suggested an immediate plan

\footnotetext{
${ }^{36}$ M. Maritz, My Lewe en Strewe (Johannesburg, 1939), pp.62-64.

${ }^{37}$ Collyer, The Campaign in German South West Africa, p.32.

${ }^{38}$ R.C. Warwick, "Reconsideration of the Battle of Sandfontein: The First Phase of the German South West Africa Campaign, August-September 1914", chapter 4; specifically pp.42-55, regarding the details of the transport and supply difficulties from Port Nolloth to Steinkopf, as well as the inadequacies by which both DHQ, besides Lukin and his field commanders, utilised the already sparsely available intelligence information.

${ }^{39}$ R.C. Warwick, "Reconsideration of the Battle of Sandfontein: The First Phase of the German South West Africa Campaign, August-September 1914", pp.126-131 where I have made an attempt at showing how the SAMR regiments were "rushed", perhaps unavoidably, from their colonial police training and experience, into the demands of modern conventional war.
} 
to occupy the wells at the location, positioned some thirty kilometres into German South West Africa. ${ }^{40}$ These constituted the only large water source between the river and the German military town at Warmbad, a point envisaged by Smuts and Defence Headquarters as a vital first bridgehead into the colony. Other sources suggested that the actual order to Lukin for ensuring the Sandfontein occupation came from Defence Headquarters in Pretoria, despite the field commander on the spot apparently indicating that the position was indefensible against artillery. ${ }^{41}$ By the time Lukin had personally arrived at Ramans Drift on 24 September, Sandfontein was already occupied by 200 UDF troops under Capt Edward Welby, whose advance into German South West Africa had been clearly observed and shadowed by the Germans, for one straggling South African Mounted Rifles man had, unbeknown to the rest of the column, been captured three miles from the wells. ${ }^{42}$ Within less than 48 hours, Lukin despatched an additional 124 white troops and 40 black "agterryers" onto Sandfontein, accompanied by a pair of thirteen pounder artillery pieces from the Transvaal Horse Artillery. This reinforcing detachment of mounted troops and artillery were under the command of Lieutenant-Colonel Reginald Grant.

Lukin had briefed Grant about enemy movement and aggressive patrols, ${ }^{43}$ speculating that an enemy force of "about three hundred" intended to attack. ${ }^{44}$ This understanding had underpinned his decision not to withdraw Welby's force from the wells, but rather reinforce and hold the position, despite the still undetermined German troop strengths south of Warmbad. Lukin had placed his faith in those intelligence reports at hand, none of which suggested that just across the river lay nearly two thousand of the enemy, well supported by artillery. He must have speculated that the German manpower resources would be dispersed and not easily capable of a rapid combined offensive. By dispatching not only just a significant portion of his limited troop numbers to Sandfontein, but also ordering the two of his four artillery pieces to accompany them, Lukin had clearly signalled his decision and intention to defend the position. On the eve of the engagement there were three squadrons of South African Mounted Rifles troops (about three hundred men) at

${ }^{40}$ South African National Defence Force, Documentation Services Directorate (hereafter SANDF DSD), GSWA, WW1, Box 15, SAMK proceeding to GSWA via Port Nolloth 191415 , telegrams $5^{\text {th }}$ Regt, telegram dated 16 September 1914.

${ }^{41}$ South African National Military Museum Library (hereafter SANMML), "Unrecorded details of Sandfontein", A416, Sandfontein, battle of.

${ }^{42} \mathrm{Rfn}$. I.G. Wessels was initially recorded as a deserter, where in fact he was captured. SANDF, DSD, GSWA, WW 1, SAMR, Box 870, Register of Deserters; SAMR, Box 647, figures examined from ledger entitled, "Casualties of War, 1914-18".

${ }^{43}$ SANMMHL, A416, Sandfontein, Battle of, Grant, written battle account.

${ }^{44}$ Collyer, The Campaign in German South West Africa, p.37. 
Ramans and Houms Drifts respectively, with six South African Mounted Rifles squadrons either en route or encamped at Steinkopf. At the same time the Witwatersrand Rifles were still en route from Port Nolloth. ${ }^{45}$ Therefore, Lukin's brigade was spread over at least five different points, lying between more than a hundred miles, yet a significant push into enemy territory was undertaken against entirely unknown odds. ${ }^{46}$

In his 1937 campaign history, utilising the official reports by Grant, Welby, and Lukin, Collyer grappled as to why Sandfontein was occupied if it had already been deemed untenable for defence. Collyer's assessment is important for, although he did not attempt to deny that a mistake had occurred in attempting to defend Sandfontein, he took great pains to defend Lukin and ignore the obvious regarding Smuts's responsibility. South African Mounted Rifles regimental commanders, Lieutenant-Colonels Berrangé, Dawson and Elliot had confirmed it was essential for the surrounding heights around the wells to be garrisoned, a point on which Welby had concurred, and explained telephonically to Lukin early on the morning of 25 September. ${ }^{47}$ A physical inspection of the battle-site makes it clear that such a widespread defence would have been difficult to achieve. ${ }^{48}$ Whatever the political pressure from Pretoria it had rested upon Lukin, as the senior field officer, to give his assent in reinforcing and attempting to hold Sandfontein. The first South African Mounted Rifles troops moved to the wells on 19 September, and although the General had only arrived at Ramans Drift on 24 September he had still been in field telephone contact with his squadron commanders for several days. ${ }^{49}$ Collyer defends Lukin by insisting that he had only judged the Sandfontein occupation as "tenable", after he had considered the opinion of "someone in whom he placed confidence". 50 There is no attempt by Collyer to suggest who this officer(s) may have been, however, there were only the regiment and squadron commanders with whom Lukin would, or should, have regularly conferred. In his own report Lukin explained his reasons for occupying the position as follows:

\footnotetext{
${ }^{45}$ Collyer, The Campaign in German South West Africa, p.35.

${ }^{46}$ R.C. Warwick, "Reconsideration of the Battle of Sandfontein: The First Phase of the German South West Africa Campaign, August-September 1914", chapter 7, where I deal in more depth with the issue of how Smuts and DHQ "pushed" Lukin's "A Force" forward.

${ }^{47}$ Collyer, The Campaign in German South West Africa, p.39.

${ }^{48}$ Personal inspections of the battlefield. There are numerous heights which surround and dwarf the Sandfontein koppie and wells. Lukin simply did not have the resources at the border by 25 September to properly defend the position.

${ }^{49}$ Collyer, The Campaign in German South West Africa, p.39.

${ }^{50}$ Collyer, The Campaign in German South West Africa, p.45.
} 
It was an important point on the line of advance contiguous to and therefore commanding the recognised roads from Warmbad to Ramansdrift and Houms Drift. It embraced the principal water holes between the above-mentioned points. Its occupation would form a bar to the enemy's reconnaissance patrols and consequently a screen to the concentration of additional troops on the line Gudous-Raman's DriftHoums Drift. It was in telephonic communication with Ramans Drift and at a distance in which it could be quickly reinforced or from which a small force could quickly retire in the face of greatly superior numbers. ${ }^{51}$

Circumstances were to prove Lukin substantially wrong regarding the assessments contained in the final sentence. In any event, as is shown above, he had not dispatched Grant's force with orders to "quickly retire in the face of greatly superior numbers". Lukin continued by describing his intention to occupy Sandfontein as: rather with a view to establishing an outpost there than with the object of obtaining a permanent footing, though the latter would be effected in the absence of powerful aggressive action by the enemy. ${ }^{52}$

\section{Culpability for the Sandfontein defeat: The debate}

Unfortunately the Germans did successfully attack the position in force. This was the result of Smuts's impatient 'forward policy' the superior manoeuvring of the German troops into battle by their leader Colonel Von Heydebreck, the inadequate intelligence reports and the poor use of those that existed, the shambolic logistical 'stretch' from Port Nolloth through Steinkopf to the river drifts, and finally, the decisions made by Lukin, who after advice from his field commanders responded affirmatively to Defence Headquarters imperatives that the German colony be immediately penetrated.

As to the identity of the person who had given the Lukin the idea that the position was tenable for defence, Collyer simply remarks: "The point should have been determined for senior officers were on the spot at the two drifts long enough to have cleared the matter up." ${ }^{, 53}$ Yet if all the officers had by Collyer's own admission rejected the idea of holding the wells, then it was Lukin's decision alone in ordering Grant and his detachment up as reinforcements, without any adequate intelligence reports. Collyer states, "the decision to hold Sandfontein itself must be judged to

\footnotetext{
${ }^{51}$ Collyer, The Campaign in German South West Africa, p.45.

${ }^{52}$ Collyer, The Campaign German South West Africa, p.45.

${ }^{53}$ Collyer, The Campaign in German South West Africa, p.46.
} 
have been a mistake". ${ }^{54}$ But what then motivated Lukin to ignore the advice of his field subordinates? It is difficult to see how an experienced soldier would have committed himself to such risk without some form of higher political pressure.

Referring to Lukin's report, Collyer correctly explained that little could have been achieved militarily by initially occupying Warmbad, considering the restricted Union Defence Force troop numbers available. The rest of 'A Force' would have remained in defensive positions at the drifts, but even more vulnerable to attack, with their already long line of communication now markedly extended into German territory. ${ }^{55}$ The Defence Headquarters 'forward policy' was never precisely defined, however, Lukin clearly interpreted it as a rapid advance into German South West Africa starting with Warmbad. The 'Ministers' had telegraphed to Lukin "that the movement of supplies to Sandfontein would be hurried on so that a move to Warmbad would not be delayed". 56 This after the General had stated that at least three weeks would be necessary to accumulate sufficient supplies on the river line, before 'A Force' could have advanced with confidence. Despite the political pressure, Lukin could have declined to reinforce Sandfontein immediately, based upon his own field appreciation, and duly informed Smuts as such. Deflecting responsibility in his own historical record, Collyer displaced his wrath upon unknown staff officers at Defence Headquarters, who had also failed to telegraph through information which had reached Pretoria on 24 September, "from two sources", concerning large numbers of German troops being entrained at the time south to Kalkfontein. ${ }^{57}$ Lukin received this information by post at Goodhouse on 7 October, and complained bitterly in his report that: "A clearer appreciation of the situation would have resulted and the outpost at Sandfontein withdrawn in ample time." 58

At his make-shift Ramans Drift Brigade headquarters on the banks of the Orange River, Lukin had listened to the sounds of the battle raging eighteen kilometres inland, where Grant's command fought for their lives against an enemy with a fourfold advantage in men and artillery. Initially reduced to a 'Chateau General', Lukin to his credit did not remain passive for long. Two South African Mounted Rifles squadrons were despatched by midday via different routes to investigate and assist, but both were skilfully rebuffed by well-positioned German forces. Only by the early morning of the following day, did Lukin personally lead

\footnotetext{
${ }^{54}$ Collyer, The Campaign in German South West Africa, p.46.

${ }^{55}$ Collyer, The Campaign in German South West Africa, p.47.

${ }^{56}$ Collyer, The Campaign in German South West Africa, p.32

${ }^{57}$ Collyer, The Campaign in German South West Africa, p.48.

${ }^{58}$ Collyer, The Campaign in German South West Africa, p.48.
} 
another South African Mounted Rifles squadron and the two remaining Transvaal Horse Artillery guns in an attempt to establish a first-hand observation of the battlesite. Collyer confronted the issue of whether enough had been attempted by Lukin to relieve Grant's force during the battle, and in all fairness, correctly concluded that the General had done his best with the troops available. ${ }^{59}$

\section{Alternative versions of Sandfontein}

This opinion was not however, shared by all veterans, for a sharp rebuttal to Collyer's judgement appeared years later in the letter pages of the Rhodesian Gwelo Times. Its contents deserve comment, more so because they could well have reflected something of the collective aftermath of veterans' resentments, rather than necessarily any factual correctness as to the Sandfontein circumstances. ${ }^{60}$ The allegations were contained in a letter published on 4 August 1950, and written by a Captain J.R.A. Kelly, a former member of the Transvaal Horse Artillery. Kelly's extraordinary accusations including that Grant's force had been "treacherously surrendered" by "4th South African Mounted Rifles members", and that one of the latter had purportedly shot Grant in the leg when the Colonel ordered the lowering of an "unauthorised white flag", raised according to Kelly, by some South African Mounted Rifles members, in response to a German call for capitulation. After Grant's 'shooting', "numerous white flags were waved and so the force was treacherously surrendered". Kelly further stated that Grant had refused to give up on account of the 'good position' he held, and had trusted Lukin to come to his assistance, something which had not occurred, because "no move was made (by the general at Ramans Drift) until night fell”.

Kelly's outrageous allegations were rounded upon ferociously by the then retired Major-General H. S. Wakefield. ${ }^{61}$ As Grant's adjutant at Sandfontein, Wakefield had been alongside the Colonel throughout the day in his sangar. The truth was that Kelly had served with the Transvaal Horse Artillery during the

${ }^{59}$ Collyer, The Campaign in German South West Africa, pp.46-47.

${ }^{60}$ SANMMHL, A.416, Sandfontein, battle of, document entitled "First Troops in S.W.A.", "Capt. J.R.A. Kelly writes" and an article from the Gwelo Times, 19 January 1957, entitled: "Cruelly False' Story of Sandfontein Battle - General Refutes Gwelo Officer's Charge". These documents are located at the back of: "Unrecorded details of Sandfontein", all located within the same folder.

${ }^{61}$ SANMMHL, A.416, Sandfontein, battle of, "First Troops in S.W.A.", Gwelo Times, 19 January 1957, entitled, "'Cruelly False' Story of Sandfontein Battle - General Refutes Gwelo Officer's Charge". 
German South West Africa campaign ${ }^{62}$ but had not been present at Sandfontein, remaining during the battle at Ramans Drift. Later he had been amongst the troops under Lukin's personal command, who during the afternoon had ridden over the river towards the battlefield in a failed effort to assist Grant. Kelly alleged that Lukin's relief efforts had been unsuccessful because the General had delayed too long, despite the urgency of Grant's dire situation, which had been clear from the intensity of artillery fire clearly audible at Ramans Drift. Wakefield correctly pointed out that Kelly's account had contained several inaccuracies and angrily refuted his allegations. Significantly however, most of Wakefield's wrath was reserved for Kelly's slander of Lukin, and the allegations regarding the misconduct of the Union Defence Force riflemen towards the end of the battle. Wakefield also completely dismissed any suggestions that further resistance would have served a purpose, or that the Germans had called upon the South Africans to surrender. He reiterated at length the complete exhaustion of the men and the heavy casualties sustained, details repetitively outlined by all the previously published Sandfontein accounts, and added that the lengthy defence of the Sandfontein wells had prevented the numerically stronger German force from overwhelming the rest of Lukin's troops at the river drifts. Finally, Wakefield abruptly referred to the historical record as outlined in Collyer's 'authoritative book'. Wakefield's strong response deserves attention, as does the deliberate lodging with the South African National Museum of Military History of copies of Kelly's letter and the documents pertaining to it. This ensured the depositor had no doubt hoped that a properly verified response to the allegations would always be available for future researchers.

The sensitivities of the Sandfontein veterans clearly ran deep, for there were other rumblings over the years that occasionally turned up in the public domain. A Nongqai article, reporting upon a South African Police squadron's trek in July 1922 during the Bondelswarts' uprising, remarked the following on this detachment spending a night at the Sandfontein wells: "From Raman's Drift we trekked via Sandfontein where everyone had the opportunity of visiting and inspecting the scene of the debacle (italics mine) in 1914". ${ }^{63}$

An obituary to Lukin written after his death in 1925, revealed further evidence of the almost hidden controversy generated by the events at Sandfontein:

\footnotetext{
${ }^{62}$ N. Orpen, The History of the Transvaal Horse Artillery. (Published by the Transvaal Horse Artillery Regimental Council, Alex White \& Company (Proprietary) Limited, Johannesburg, 1975), Appendix 12, Muster roll of the Regiment 1904-1926, Kelly served in the THA during 1906-08, 1910-12, 1914-15, and 1922.

${ }^{63}$ The Nongqai, September 1922, p.502.
} 
It was an engagement that easily lent itself to criticism. First, on the grounds that this small detachment should not have been thrust forward into enemy territory, and secondly, that Colonel Grant had shown bad tactics in allowing himself to be pinned down to an action with greatly superior numbers. There was even a suggestion for some time that General Lukin had received orders from Pretoria to make the advance even at the risk of disaster, so that the eyes of the country would be opened to the danger of the situation. ${ }^{64}$

Kelly's account may at best have reflected some of the gossip in Transvaal Horse Artillery and military circles that continued over the years. This and other 'alternative versions' endorse the existence of a barely muted controversy regarding the battle circumstances, and the fact that the events prior to the engagement were never officially investigated. As a result, a variety of different stories were promoted and circulated. Rumours ensued about culpability, while bitterness would have lingered regarding the Union Defence Force deaths and injuries, and the hardships suffered by the many prisoners of war. Some of these feelings were reflected in Corporal Young's 1955 account of the Cape Mounted Rifles/ $1^{\text {st }}$ South African Mounted Rifles history when he wrote:

As far as the general public is concerned, the incidents of the Sandfontein tragedy have never been made known. And it may be as well to chronicle a few facts which will go to show that the Government of the day was rashly impolitic in sending a handful of men to hold Sandfontein. It was a critical time on the German border... There was a little cemetery lying a short way beyond the hill. Our dead and the German dead were buried there. Somewhere, somebody still remembers them. ${ }^{65}$

Kelly remained a member of the Transvaal Horse Artillery until 1922 and would have been privy to the mutterings amongst its members during the years directly after the battle. His details also suggest the confusion of the last moments in the battle, embellished by ill-feeling and myth, as old soldiers like himself in their sixties and seventies, needed to rationalise, artificially boost, or make sense of past disappointments and grievances. Although the truth of Kelly's allegations is highly questionable, the Union Defence Force Sandfontein officers and their scribes still

\footnotetext{
${ }^{64}$ The Cape Argus, 16 December 1925, p.5.

${ }^{65}$ P.J. Young, Boot and Saddle, A Narrative Record of the Cape Regiment, the British Cape Mounted Riflemen, the Frontier Armed Mounted Police, and the Colonial Cape Mounted Riflemen (Maskew Miller Limited, Cape Town, 1955), pp.160-161.
} 
remained the only custodians of the Sandfontein battle history. ${ }^{66}$ Besides Collyer and Young's account, little else after the late 1920s was written on the battle and its prior circumstances.

\section{Events on the German South West Africa border following Sandfontein}

The next few days after Sandfontein were undoubtedly amongst the most stressful that Lukin could have experienced in his military career. Because Lukin by the morning of the $27^{\text {th }}$ he did not in any way have at his disposal the manpower to pursue Von Heydebeck's comparatively huge troop numbers, the General retreated with his attempted relief forces back to the river drifts. 'A Force' was now even more scattered than previously, and still operating upon the most tenuous lines of communication and logistics. Upon returning to the river, Lukin immediately ordered entrenchment on the German bank. ${ }^{67}$ However, later that day, he withdrew the entire brigade, intending to march all the way back to Steinkopf, including the 2nd and 3rd South African Mounted Rifles regiments who had just completed riding the tortuous fifty miles from the town up to Ramans Drift. ${ }^{68}$ Lukin enforced the retreat because of the German Sandfontein force's strength and the bewildering speed at which it had operated. ${ }^{69} \mathrm{He}$ was particularly concerned that the Germans could have crossed the river elsewhere and cut off his force from their advanced base camp at Steinkopf. ${ }^{70}$ However, Collyer also refers to a telegram from Defence Headquarters received on 27 September, ordering the retreat to Steinkopf "on account of Maritz's attitude". ${ }^{71}$ While his men were in the process of withdrawing, some ten miles south-west of Ramans Drift, Lukin once again changed his mind and decided to return his entire command back to the river. Collyer records that this was

\footnotetext{
${ }^{66}$ Besides Collyer and the Official History already referred to and the official reports of Lukin, Grant and Welby, all three of which were utilised by Collyer, the longest account was written by one of the battle's veterans, Nongqui, October 1916, Lt D.S.G. Scott, The Story of Sandfontein. To this can be added the specific chapter in Rayner W.S. \& O'Shaughnessy, W.W., How Botha and Smuts Conquered South West Africa (1916), and Adler, F.B., The History of the Transvaal Horse Artillery, Johannesburg, 1927. I also used a number of German accounts in my thesis, the most prominent of these were Hennig, R., Deutsch-Sudwest in Weltkrieg (Berlin: Verslag Susserott, GmbH, 1920), Seitz, Theodor, Sudafrika im Weltkrieg (Berlin: Dietrich Reimer, 1920), and Von Oelhafen, H. Der Feldzug in Sudwest 1914/15/ (auf Grund amtlichen Materials bearbeitet von Hans Von Oelhafen; herausgegeben von der Gesellschaft fur kolonialen Fortschritt.- Berlin: Safari Verslag, 1923).

${ }^{67}$ SANMMHL, folder A416, Sandfontein, Battle of, document entitled "Unrecorded details of Sandfontein. Some impressions of men who were there".

${ }^{68}$ Collyer, The Campaign in German South West Africa, pp.48-49.

${ }^{69}$ Collyer, The Campaign in German South West Africa, pp.48-49.

${ }^{70}$ SANMMHL, folder A416, Sandfontein, Battle of, document entitled "Unrecorded details of Sandfontein. Some impressions of men who were there".

${ }^{71}$ Collyer, The Campaign in German South West Africa, p.49.
} 
Lukin's own decision, but then refers to another telegram from Defence Headquarters that "expressed the view that 'A Force' was strong enough to hold the Orange River position, and that a retirement would enable the enemy to pay attention to the smaller forces under Maritz and Beves". ${ }^{72}$ Maritz had by this stage still not formally declared his rebellion against the Union government. Such were the difficulties and indecisiveness experienced and exhibited by both Lukin, and what must have been instructions from government level emanating via Defence Headquarters.

New positions were therefore taken up by Lukin's men at Carl Weidner's Orange River Farming Syndicate at Goodhouse. ${ }^{73}$ Another source suggested that Lukin once again split up his command, in order to cover all three drifts along the thirty-six kilometre river stretch where the Union Defence Force had operated. ${ }^{74}$ The 5th South African Mounted Rifles Regiment had returned early to Steinkopf because of "state of their horses", and this regiment during the next three to four weeks despatched scouting patrols back towards the border. ${ }^{75}$ The General's biographer grimly described the situation at Goodhouse as being "a post on the Orange River in a dangerously exposed position with no support within hundreds of miles". ${ }^{76}$ Lukin himself purportedly remarked: "The Germans could have eaten us up if they had made a bold bid". ${ }^{77}$ However, the reality was that the Sandfontein German force had long gone and the General was now watching a border area virtually devoid of the enemy.

The stress of the Sandfontein defeat and the uncertainties regarding the German strengths and intentions, had clearly however began to take their toll on Lukin, for an extremely strained relationship developed almost immediately between himself and Weidner, the clearly reluctant host. On the night of 28 September nearly two thousand military personnel had descended upon Weidner's farm, considerably more than the manager's initial tolerance would allow. Within a day there was an angry altercation between Weidner and Lukin over several issues, including it appeared suitable accommodation for the General, besides the intimation of a demand by the manager for compensation. Certainly food and fodder were in short

\footnotetext{
${ }^{72}$ Collyer, The Campaign in German South West Africa, p.49.

${ }^{73}$ Collyer, The Campaign in German South West Africa, p.49.

${ }^{74}$ SANMMHL, folder A416, Sandfontein, Battle of, document entitled "Unrecorded details of Sandfontein. Some impressions of men who were there".

${ }^{75}$ Memoirs of A.E. Bishop, a 5th SAMR regiment veteran, posted to me in March 1998 by his son E.J.B. Bishop of Summerstrand, Port Elizabeth.

${ }^{76}$ Johnstone, Ulundi to Delville Wood, p.120.

${ }^{77}$ Johnstone, Ulundi to Delville Wood, p.120.
} 
supply $^{78}$ and demands for their requisition were almost definitely also at the root of this civilian-military antipathy. Lukin was in no mood for any other kind of defeat. Severe pressure of some description occurred, eliciting a cringing response from Weidner:

Sir, I would consider it a great favour if you would accept my apology for my behaviour towards you this morning... I would also thank you if you considered my business letter of this morning as never written and I assure you that myself, personnel and property, are ready to render whatever assistance we can in our own humble way to make your difficult task a little easier in these parts. I will only consider my apology fully accepted if you will make full use of my own house (leaving me one room) as if it was your own during your stay in Goodhouse. If I am not about please walk into my home as it is left open for you. ${ }^{79}$

After the Sandfontein defeat there were unsurprisingly no gushing references to Lukin in the press. Neither were the military writings on the German South West Africa campaign of such a content and style that in any way elevated him, as occurred later in the aftermath of Delville Wood. Sandfontein was the fledgling Union Defence Force's first battle and it had ended in sound defeat. Unlike the legacy of Delville Wood, the Sandfontein battle received no official prominence, because political tensions were still acute within the white community. Even amongst members of the white English-speaking working class on the Witwatersrand, who had clashed with the state eight months earlier in industrial action, there was some sneering satisfaction at the reverse. One anonymous correspondent penned the following to Smuts: You just try to take GSWA as you darkly hint... and we will see some fun. You will get plenty of magnified Zandfonteins. ${ }^{80}$

\section{Sandfontein in official military history}

The government and Smuts had no interest in pursuing any investigation into the defeat. Indeed this reality was even more obvious once the first German South West Africa campaign accounts were written. The Afrikaner Rebellion had been the government's highest priority in late 1914 and early 1915, and in the

\footnotetext{
${ }^{78}$ Johnstone, Ulundi to Delville Wood, p.120.

79 SANDF, DSD, Box 15, GSWA, WW I, SAMK Proceeding to GSWA via Port Nolloth, Letter from Weidner to Lukin; 30 September 1914.

${ }^{80}$ African Studies Manuscripts Collection, UCT, Smuts Private Letters, Vol 12, 1914.
} 
aftermath of its suppression, a united South African Party/Union Defence Force front appeared, together with a strong condemnation of Maritz. The latter was vehemently accused in all campaign and official accounts of being responsible for the Sandfontein defeat by not drawing off part of the German attackers. ${ }^{81}$ With the completion of the rest of a highly successful German South West Africa Campaign in mid-1915, it would have been politically expedient for the South African Party to play Sandfontein and its controversies down, detracting as these were from the gloss of final victory. The failures by Lukin's force along the Orange River border during September-October 1914 would have given political opponents ready ammunition against Smuts. It therefore made political sense, as far as the government was concerned, to paint as black a picture of Maritz as conceivable, and divert the entire blame for Sandfontein onto him. Such a projection of sole responsibility was not difficult to achieve, considering that his behaviour had been traitorous in the opinions of many from both the Afrikaner and English-speaking white communities.

Lukin, Grant, and the other Sandfontein Union Defence Force officers were 'establishment men'. Whatever private feelings they may have had, they were not prepared to break from their clearly understood positions as military officers. They would not have related radically alternative accounts, but accepted the defeat as a "misfortune of war", the very expression conveyed to Lukin by 'Pretoria' in response to a communication by Lukin to Defence Headquarters, suggesting the holding of an inquiry into the Sandfontein defeat. ${ }^{82}$ Grant received the same kind of distanced response when he submitted a report to Smuts on 24 August 1915.

I am to state, without expressing any opinion on what preceded the fight at Sandfontein - choice of position, reconnaissance and so forth - the Minister is convinced that your own behaviour in the action was in every way soldierlike and that no blame attaches to you for the surrender of our troops on the occasion referred to after the gallant resistance. ${ }^{83}$

The various accounts of Sandfontein and the German South West Africa campaign formed the beginnings of a South African First World War historiography.

\footnotetext{
${ }^{81}$ The same theme of placing all the blame for Sandfontein upon Maritz comes up regularly in most of the South African accounts. I have tried to place this more clearly into perspective; see R.C. Warwick, "Reconsideration of the Battle of Sandfontein: The First Phase of the German South West Africa Campaign, August-September 1914", pp.178-182.

${ }^{82}$ SAMMHL, A416, Sandfontein, Battle of, "Unrecorded details of Sandfontein. Some impressions of men who were there".

83 SAMMHL, A416, Sandfontein, Battle of, "Unrecorded details of Sandfontein. Some impressions of men who were there".
} 
The authors were not however historians, but journalists or army officers tasked with a scribe's function, and to the man supportive of South African Party government policy. Their works vary in quality and detail, but reflect the one-sidedness of any wartime propagandistic writings. The Official History, Collyer's book, an account by Raynor \& O'Shaughnessy, ${ }^{84}$ and the relevant articles in Nongqai, all cover the entire GSWA campaign in varying detail, but it is their context and purpose which requires clarification. While these writings all made some reference to Sandfontein, this was not the case with Moore Ritchie's With Botha in the Field, which omitted the battle entirely, making its specific focus the second and main phase of the campaign. ${ }^{85} \mathrm{~W}$. Whittall's With Botha and Smuts in Africa, ${ }^{86}$ also completely ignored the pre-Rebellion phase of the campaign, as did J.P. Kay Robinson's, With Botha's Army. ${ }^{87}$ Collyer's The Campaign in German South West Africa 1914-1915, has been considered the standard authoritative text by South African military history enthusiasts for seven decades, however, a fourth book, Urgent Imperial Service by Gerald L'Ange ${ }^{88}$ also warrants mention, not least for the fact this was the first attempt since Collyer in 1937 to write a full campaign history. There also exist a wide range of biographies and regimental histories, containing very short reports on events in German South West Africa during 1914-15. The Nongqai articles, the Official History, and the Rayner \& O'Shaughnessy account, were published almost contiguous to the campaign, but contain no footnotes and references to assist in verifying specific details. Collyer apparently did consult some of his predecessor's writings and official documentation, besides drawing upon his own recollections.

At the time of Lukin's death in 1925, the political differences in white politics were raging as hot as ever, which may help to explain some of the veneration which he enjoyed from his old comrades, most of whom would have been South African Party supporters, wary of the nationalists who formed the larger proportion of the new Pact government after 1924. The Official History, published as it was a few months before the Pact government's election victory, takes us a little closer to understanding the extent to which the SAP government specifically determined the selective recording of the Sandfontein defeat. The book exemplifies the South African Party government's determination to play down any suggestion of poor generalship or the poor tactical handling of troops. Van der Waag gives a clear

${ }^{84}$ W.S. Rayner \& W.W. O'Shaughnessy, How Botha and Smuts Conquered South West Africa, Simpkin, Marshall,Hamilton, Kent \& Co., Ltd, Stationers' Hall Court, E.C., 1916.

${ }^{85}$ M. Ritchie, With Botha in the Field (London, 1915).

${ }^{86}$ W. Whittall, With Botha and Smuts in Africa (Cassell and Company, Ltd., London, 1917).

${ }^{87}$ J.P. Kay Robinson, With Botha's Army (George Allen \& Unwin Ltd., London, 1916).

${ }^{88}$ G.L'Ange, Urgent Imperial Service, South African Forces in German South West Africa, 1914-1915 (Rivonia, 1991). 
outline of this publication's multi-authorship: it was Johan Leipold who assembled the final publication. Leipold had seen active service in both the South-West and German East Africa campaigns, and brought together various drafts of official campaign histories, besides additional sources and his own writings, to complete the Official History. ${ }^{89}$ The book's preface makes its objective explicit; it was to serve an "inspirational end", ${ }^{90}$ meaning in this case, the official veneration of the South African contribution in World War One via a single 'authoritative' volume. The introduction concerning the German South West Africa campaign reads triumphantly: "One of the most clear-cut and ideal campaigns in history." 91 This stands in stark contrast to this paper's contention that the Sandfontein defeat was indisputably part of the campaign, and the loss resulted from a consequence of errors of judgement by Defence Headquarters, namely Defence Minister Smuts, exacerbated by decisions made by General Lukin while he was under political pressure. However, as is illustrated from the quote below, drawn from the Official History, this failed 'first phase' of the German South West Africa invasion, was explicitly excluded from the campaign parameters.

The actual German South-West campaign... may be taken as having commenced after the Union Government had restored order within the Union-that is from $1915 \ldots$ Our chief concern here... would be not to obscure what was simple and successful. ${ }^{92}$

Events involving the Union Defence Force in German South West Africa before 1915 are simply marginalised as "obscuring what was simple and successful". In contrast the rest of the campaign was presented as a model success against others that were more costly and tactically inconclusive, namely the heavy tolls of dead and injured suffered by the South African Brigade in France, and amongst the Union troops during the German East Africa campaign. In the Official History, the problems in the German South West Africa campaign first phase received careful explanation, with contestable details either played down or simply ignored. Botha's post-Rebellion invading force was congratulated for a "rapid and well-directed action" in which the Union Defence Force "could obtain great results inexpensively". Their overall feats in German South West Africa were favourably

\footnotetext{
${ }^{89}$ I. van der Waag, Contested Histories: Official History and the South African Military in the Twentieth Century, pp.29-36, in J. Grey, ed., The Last Word? Essays in Official History in the United States and British Commonwealth (Westport, 2004).

${ }^{90}$ J. Keegan, The Face of Battle: A Study of Agincourt, Waterloo, and the Somme (London, 1974), p.18.

${ }^{91}$ See Official History, Preface.

${ }^{92}$ See Official History, Preface.
} 
compared with other campaigns where South African troops served. The Official History's verdict was "judged from the viewpoint of results, the rebellion and SouthWest campaigns must come first". ${ }^{93}$ The Official History created an explicitly positive record of the South African World War One contribution. It excluded any hint of emotional indulgence, for its intention was the inculcation and reinforcement of patriotism and national pride amongst white South Africans. By ensuring the celebration and public promotion of the Defence Force's war deeds, honour, and successes, The Official History's content was also intended as a boost to the ruling South African Party. The Union Defence Force was potentially a powerfully visible unifying symbol for whites, and had during the war, drawn from the young manhood of both English and Afrikaans communities. As the South African Party voter support dropped off during the early 1920s, the government was concerned about ensuring the most politically advantageous portrayal of the Defence Force and its activities during the war. Therefore, any possible controversies, such as the events leading to Sandfontein and the battle itself, were ensured careful and sympathetic explanation in official publications. ${ }^{94}$

While Collyer's publication on the German South West Africa Campaign was considered the authoritative work by generations of South African military writers, he had also during his military career been involved within the inner circle of the most prominent government and military figures, and this would have done much to shape his own loyalties. It was therefore inconceivable that this devoted soldier and civil servant would have ever delivered personalised criticism to a politician as highly placed as Smuts, who by 1937 , when the book was published, held the office of Deputy Prime Minister within in the United Party government under Hertzog. Collyer never intended to conduct too thorough an investigation into Sandfontein. It was an issue that would have been potentially highly contentious, given that most of the individuals involved were still alive in 1937, and that much of the volatile 1914 political context remained highly relevant within late 1930s white South African politics.

${ }^{93}$ Official History, Preface.

${ }^{94}$ See also I. van der Waag's article: Contested Histories: Official History and the South African Military in the Twentieth Century, in J. Grey, ed., The Last Word? Essays on Official History in the United States and British Commonwealth (Westport, 2003). In pp.29-36 of Van der Waag's article, it is very apparent how close the various contributors to the Official History were to Smuts and the SA Party's thinking. This would endorse the point made within this paper that the Official History's omission of the Sandfontein defeat was politically intended, for the reasons which are shown above. 


\section{Conclusion}

Sandfontein had been a disaster for both the Union government and its Defence Force, and a political embarrassment that was carefully reshaped in official military history, despite the chagrin that emerged years later from individual veterans. In their commemoration of Lukin by the early 1930s, Collyer, Grant, and the other Sandfontein officers, would not have publicly aired controversial views on UDF's history and their roles therein. Professional habits, the political position of Smuts by 1932, their broader support of government policy, and perhaps their own sense of humility shaped by years of eventful soldiering, would have tempered any outspokenness. As the statue of General Lukin was unveiled, it was not Sandfontein and the prior circumstances to the Union Defence Force's first battle and defeat that would have been brought to the fore during proceedings. It was rather white South African society during the grim days of the depression, trying to celebrate the life of one of their heroes who had stood out during the preceding two decades, and who for better or worse, had represented fortitude and duty against all odds. The statue unveiling was also intended to demonstrate one of white South Africa public displays of political unity, oblivious as this community was at the time to the larger political settlement that inevitably awaited their grandchildren.

Both Lukin's resilience and fallibilities had been obvious during the German South West Africa campaign. If he and Smuts had perhaps been more realistic regarding the limitations of 'A Force' during September 1914, the Sandfontein defeat may have been avoided. No doubt Collyer and Grant understood this as they honoured their old comrade during that early Cape autumn of 1932. As a loyal civil servant Lukin had continued to serve his country honourably as a soldier, and later still, as a friend to the thousands of soldiers he had once commanded with such stern justice. The camaraderie and loyalty of his men, undeniably manifested by the thousands who lined the route to Plumstead cemetery in December 1925, was hardly an emotion that could have been feigned. His statue today in Cape Town's Company Gardens may represent little to most South Africans, but his values of selfless and uncomplaining civil service, have a vital place in the successful future of the land that Henry Timson Lukin adopted as his own.

\section{Bibliography}

\section{Unpublished}

\section{National Archives, Cape Depot, Cape Town}

Defence Department (DD) 
Vol 1\145 Ref C1129

South African Museum of Military History Library, Johannesburg

Folder A.416 Sandfontein, Battle of

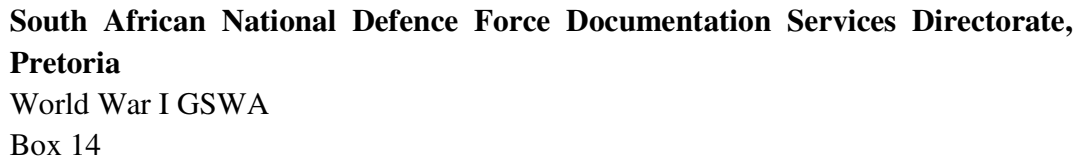

South African National Defence Force Documentation Services Directorate, Pretoria

World War I GSWA

Box 14

South African Mounted Rifles (SAMR)

Vol. 3

Box 647

Vol. 4

Box 870

University of Cape Town: Centre for African Studies

Smuts Private Letters Vol.12 1914, J.C. Smuts No. 1-12

Correspondence received from Bishop, E.J.P. (Unpublished memoirs of his father).

\section{Published}

Moth’s Annual, 1928

\section{Newspapers}

Cape Times, March 1932

Cape Argus, March 1932 and December 1925

Die Burger, March 1932

\section{Journals}

The Nongqui, August 1920, September 1922

\section{Books}

Adler, F. B., The History of the Transvaal Horse Artillery, Johannesburg, 1927.

Collyer, J.J., The Campaign in German South West Africa, 1914-15, Government Printer, Pretoria, 1937.

Digby, P.K.A., Pyramids and Poppies, The $1^{\text {st }}$ SA Infantry Brigade in Libya, France and Flanders 1915-1919, Ashanti Publishing, Rivonia, Johannesburg, 1992.

Grey, J. ed., The Last Word? Essays in Official History in the United States and British Commonwealth, Westport, 2004. 
Grundlingh, A., Fighting their Own War - South African Blacks and the First World War, Ravan Press, Johannesburg, 1987.

Herd, N., 1922, The Revolt on the Rand, Blue Crane Books, Johannesburg, 1966.

Johnston, R.E., Ulundi to Delville Wood, The Life Story of Major-General Sir Henry Timson Lukin K.C.B., C.M.O., D.S.O., Chevalier Legion D'Honneur, Order of the Nile, Maskew Miller, Ltd., Cape Town, 1929.

Jooste, G. \& Webster, R., Innocent Blood - Executions during the Anglo-Boer War, Spearhead, Claremont, Cape Town, 2002.

Keegan, J., The Mask of Command, Jonathan Cape Ltd, London, 1987.

Keegan, J., The Face of Battle: A Study of Agincourt, Waterloo, and the Somme, London, 1974.

Keegan, J., The First World War, Pimlico, London, 1998.

L'Ange, G., Urgent Imperial Service, South African Forces in German South West Africa 1914-1915, Ashanti Publishing, Rivonia, Johannesburg, 1981.

Maritz, M., My Lewe en Strewe, Johannesburg, 1939.

Official History, Union of South Africa and the Great War 1914-18, Government Printer, Pretoria, 1923.

Orpen, N., The History of the Transvaal Horse Artillery, Published by the Transvaal Horse Artillery Regimental Council, Alex White \& Company (Proprietary) Limited, Johannesburg, 1975.

Rayner, W.S., and O'Shaughnessy, W.W., How Botha and Smuts Conquered German South West, Simpkin, Marshall, Hamilton, Kent \& Co., Ltd, Stationers' Hall Court, E.C., 1916.

Steenkamp, W., Soldiers, Cape Town, 1978.

Uys, I., South African Military Who's Who 1452-1992, Fortress Publishers, Germiston, 1992.

Van der Byl, P., From Playgrounds to Battlefields, Howard Timmins, Cape Town, 1971.

Von Oelhafen, H., Der Feldsug in Sudwest 1914/15, auf Grund amtlichen Materials bearbeitet von Oelhafen; herausgegeben von der Gesellschaft fur kolonialen Fortschritt.-Berlin: Safari Verslag, 1923.

Warwick, G.W., We Band of Brothers: Reminiscences from the $1^{\text {st }}$ SA Infantry Brigade in the 1914-18 War, Howard Timmins, Durban, 1962.

Young, P.J. Boot and Saddle, A Narrative Record of the Cape Regiment, the British Cape Mounted Riflemen, the Frontier Armed Mounted Police, and the Colonial Cape Mounted Riflemen, Maskew Miller Limited, Cape Town, 1955. 


\section{Articles in Journals}

Grundlingh, A., The King's Afrikaners? Enlistment and Ethnic Identity in the Union of South Africa's Defence Force During the Second World War, 1939-45, Journal of African History, 40, 1999.

Nasson, W., War Opinion in South Africa, 1914, The Journal of Imperial and Commonwealth, Volume XXIII, Number 1, January 1995.

\section{Paper delivered}

Nasson, W., Springboks at the Somme: The Making of Delville Wood, 1916, Seminar Paper presented on 21 October 1996 at the University of the Witwatersrand, Institute for Advanced Social Research.

\section{Dissertations}

Ungleich, T.R. The Defence of German South West Africa during World War I, Master of Arts Dissertation, University of Miami, 1974.

Warwick, R.C. Reconsideration of the Battle of Sandfontein: The First Phase of the German South West Africa Campaign, August to September 1914, Master of Arts Thesis, University of Cape Town, February 2003. 